\title{
Enduring Characteristics and Unstable Hues: Men in Black in French painting in the 1860s and 1870s.
}

\author{
$\underline{\text { Introduction }}$
}

In 1890 Edgar Degas purchased an enormous portrait of a subject who was not a friend or relative and displayed it on an easel in a huge bare room where it remained until his death in 1917. This was Eugène Delacroix's now celebrated portrait of the Parisian dandy Baron Schwiter in formal black day-wear. ${ }^{1}$ The respect in which Delacroix was held by the generation of Edouard Manet and Degas may account for this purchase. After all, Henri Fantin Latour had already in 1864 depicted the company of artists, a team of men in black before a portrait of their revered forebear. ${ }^{2}$ I want to suggest, however, that Delacroix's celebration of men's fashionable dress, the male in his public persona, carried particular provocation for Degas and at times also for contemporaries such as Manet, embodying a lifelong curiosity over male subjects in clothing that did not merely cover the body or exemplify fashionable dress but established a dialogue of materiality between what was worn and what was painted. By materiality I mean the agency and meaning of material itself as an essential factor in the power to create presence. ${ }^{3}$ It is not so much a question of how black was worn but of how the very act of wearing might interpenetrate with acts of representing in ways that inflect the passage of time and the marks it leaves. The history of dress has paid far more attention to the clothes worn by women than to those worn by men. Nonetheless, described as quintessentially ambiguous, 'thick stuff or nothingness', ${ }^{4}$ the history of black has recently attracted cultural historians, neuroscientists, linguisticians, literary scholars, fashion historians, intellectual historians and mythographers. ${ }^{5}$ For all their intrinsic interest, these studies seldom address the complicated interaction between materiality and the referentiality of works of art. 'Black' comes in many hues and men's clothes, while uniformly dark, were often merely an approximation of black for reasons that will be discussed. The orthodox view is that men in their dark clothes were a foil to women's brilliance: in Barbara Vinken's words: 'Fashion has never more rigorously divided the sexes than in the nineteenth century. "His" eternally inconspicuous dark suit provides the ideal matt background before which "she" can spring into life with the brilliance of silk, the sparkle of jewels, the shimmer 
of naked skin, and the ivory of the décolleté. ' ${ }^{6}$ John Harvey has similarly, and effectively, both in Darwinian and in social terms mapped the sexual power of black fashion as it transmuted from asceticism. ${ }^{7}$

In 1881, Manet portrayed the journalist Henri Rochefort three-quarter length (pl.1). Much is known about this politically radical sitter but I shall not linger on his deportment with hidden hands, unhappy expression and wild hair. Bypassing empathetic biographical readings I focus on manufactured materials and their resonances. Rochefort's tailor has made his clothes in drap (wool) reminding us of Balzac's remark that the French Revolution was also a question of fashion, a debate between silk and drap; ${ }^{8}$ in an endorsement of class, Rochefort wears a ruby stud in his shirt front. Drap might be quite soft and malleable but that used for coats in the second half of the nineteenth century was a boiled felt-like cloth that was to a degree waterproof. The third type of cloth was velours (velvet). ${ }^{9}$ As men were at this period so uniformly clad, cut and texture were especially significant. Rochefort's cuff is edged with a fluid but firm line of black. So we might notice how the starched linen is sharply delineated with a dragged effect at the edges perhaps resulting from having been painted wet over dry; the running lines thus produced distinguish the boundary between linen and wool. This is one of very few clear-cut boundaries in this portrait, perhaps in recognition of the importance of linen to class and status. While the haptic character of paintwork is often visible in raking light in black or dark areas, it is in the whites of linen that the material relationship of artist to canvas is made vividly apparent. It is almost as though the labour intensive care of linen demanded an unequivocal vehemence in its representation. Linen was important for more than aesthetic reasons. As one writer asserted in 1844 , the introduction of linen was one of the revolutions in hygiene of the era, allowing the shirt to absorb secretions from the skin and by its tactile properties gently to stimulate the skin without provoking exhalations. ${ }^{10}$ A man was judged, it has been proposed, on the impeccability of his cuffs, shirt collar and tie. ${ }^{11}$ However, vestimentary practices can be as ambiguous as the uncertain boundaries of paintwork in a portrait: Rochefort's standing collar reminds us of Walter Benjamin's reference to: 'all that the shirt collar signifies' when the layman in the latest fashion and the priest are indistinguishable. ${ }^{12}$ By contrast with his linen, Rochefort's wool coat is painted in soft slurry strokes creating a fuzzy outline of the body with deep shadow where the soft cloth has adjusted into dips and folds to accommodate a body that is here, by contrast with cloth, immobile. Oil paint whose fluidity is declared in the trace left by a brush contrasts with, and serves as substitute for, the lack of mobility in the depicted bodies. 
My question is what does this way of painting convey of the character and process of the wearing of these garments? Did the ambiguity and apparent unfinish in these portraits signal indecision on the part of an artist or does it evince a late nineteenth-century entanglement between humans and materiality? In which case where did it come from? Or did it also involve a permutation in the relationship between what was depicted - dress - and the actual ways in which a painter might conjure that dress in all its material as well as in its social signification. There are four intersecting technologies (that are also attribute values) that are critical to this study: painting, dyeing, tailoring and photography. Three artists are the focus of my attention: Manet, Fantin Latour and above all Degas. Rather than asking first and foremost what is being shown in the painting, when and how was such an item worn, and with what effect, I argue for the recognition of a system of overlapping material practices in which both the texture and the textuality of clothing and their production intersects with, and informs, the preoccupations of the artist. I propose technologies of representation (such as painting and photography) that do not illustrate dress but are in active engagement with it. My primary purpose in this essay is therefore not that of identification but an attempt to forge a new way of understanding the relationship of painting to dress. I use the term technology here to mean branches of knowledge that apply that knowledge to practical ends. ${ }^{13}$

One final point of contextualisation is needed. I have no interest in accounts of the great march of fashion in which one style or detail of dress gives way to another with clothing itself appearing to work as agency for those changes. ${ }^{14}$ Descriptors such as 'parure' are endowed with a life independent of those who make the materials, sew the garments, sell them and wear them, or indeed those who represent them and on whose evidence we now often rely for our historical judgements. So we learn that: ' à partir du Second Empire, une typologie vestimentaire se fixe autour de la redingote, de la jaquette, de l'habit .... ${ }^{15}$ (From the time of the Second Empire, a clothing typology was established around the overcoat, jacket and suit). It is difficult to reconcile these narratives of change driven by some unspoken internal compulsion with recent research that demonstrates just how fractured and confused were social practices within which clothing and fashion had a presence. Second hand clothes (presumably by their nature no longer fashionable) were not necessarily less expensive than new clothes and the boundaries between new and old were blurry. This is reflected in the multiple titles given to those who sold clothes. A tailor might also be a second hand clothes merchant while a tailleur-brocanteur might alter clothes bought second hand and make them more fashionable. ${ }^{16}$ While 'the general lines and silhouette of male 
dress in this period were unusually stable', ${ }^{17}$ it is equally the case that the complexity of notions of clothing, materials, history and fashion - as well as the clothing itself - make this period anything but stable. Writers pointed to a crisis of quality of textile and dye. ${ }^{18}$ Men's clothing circulated, eventually ending up as rags; the point at which it might be finally discarded was determined by how worn it was, how unadaptable to fashion, or by fear of contagion, as with contamination caused by spittle from a tuberculosis victim. And at each stage garments, not least military uniforms, were transformed, dyed, modified and re-made. ${ }^{19}$

\section{Painting and Tailoring}

The paintings that interest me are full of depictions of garments that we know to have been made individually by tailors, even if at this moment in the 1860s and '70s the mass production of clothing was transforming the market. The first lock stitch sewing machine was patented in 1846 and fashion magazines began issuing paper patterns around the same time. ${ }^{20}$ It was also during the nineteenth century that the tape measure (invented in 1799) came into common use and the systematisation of cutting was established using

proportionate tables and scales. ${ }^{21}$ So what might we do with this historical knowledge, aside from identifying garments by reference to fashion plates? Even this is risky since these images have a promotional function and, with their own visual economies, cannot stand as an unproblematic referent. The orderly progression of style so rigorously conveyed by fashion magazines belied the threat of impermanence and inauthenticity to which la mode (meaning both fashion and the fashion industry) was subject. In a letter to Louise Colet in 1854, Flaubert asserts that in this world of merchandise, the omnibus (a conveyance that brought together strangers) demonstrates the death of the bourgeoisie. Everyone looks the same as they all wear the same clothes, and here he names among other men's garments the paletot (a kind of loose, all enveloping coat that was criticised as it was perceived as democratising). ${ }^{22}$ A paletot is included in a fashion plate (pl. 2) in which the models are posed in an imaginary artist's studio in which all the signifiers of une vie de Bohème have morphed into a sequence of pictograms. In Degas's portrait of Edmondo Morbilli and his wife, Thérèse (Degas's sister) (pl. 3), Edmondo wears a paletot but for all that there is a garment type in common, the differences are far greater than the similarities. It is useful to turn again to Flaubert and what he terms 'this great confusion'. La mode, a word that comes from Latin for 'measure', is a thing of the past, he argues, because there is no longer any 
authority. Without la mode there is anarchy, and each person is given up to his caprice. ${ }^{23}$ The paletot was particularly confusing. According to Eugène Chapus, because its anonymity rendered invisible what was worn beneath, the paletot meant the breakdown of hierarchies of dress for men. ${ }^{24}$ The enveloping nature of this garment, which may also be seen worn by Gustave Courbet's patron Alfred Bruyas in a painting that thematically challenged established social relations, ${ }^{25}$ was potentially a cipher for deceit; it was a garment that might inauspiciously conceal the true nature of its wearer. At the same time a tailor might make an individualised bespoke version of this garment as appears to be the case with Morbilli and Bruyas.

If we set aside these vestimentary conflicts and think about what matters to tailors and how they go about their business, new lines of enquiry are possible. Both tailor and artist start with cloth. The shared origin of text and textile in the Latin Texere (to weave) and Textus (a tissue) is a critical commonplace, albeit a rich one. ${ }^{26}$ Textiles are one of the most ubiquitous components of material culture, and paper on which artists like Degas drew was originally made from rags. Working in textiles shares a common language with the making of flat art: piece, fabricate, cut, mesh, layer. The qualities that epitomised a good drap such as went to make Rochefort's frock coat or Morbilli's paletot were fourfold: la force (strength), le brilliant (sheen or surface luminosity), le grain (texture) and le teint (dye or colour). Then, as now, price determined quality as was also the case with the canvases purchased by artists. A tailor describing the texture of a good drap might equally be describing a painting: 'Le grain qui ne fait rien à la bonté d'un drap contribue à sa beauté; c'est une petite ondulation qu'on aperçoit en le regardant de très-pres et dont un oeil exercé peut seul distinguer les reflets plus ou moins larges' (The grain which does nothing for the quality of a cloth contributes to its beauty; it is a slight undulation which can be seen when looking at it very closely and of which the trained eye can only distinguish a more or less general sheen). ${ }^{27}$ Many aspects of what we now understand as textuality - especially perhaps the undecidable character of the text and the idea that it is a surface over which the reader can range in any way the text permits - apply equally to clothing devised by a tailor with its hidden or semi-obscured components and surprises.

For a man's tailor the cloth was wool from a roll. In the case of the artist, it was a length of canvas (at this time linen) also cut from a roll and probably ready-prepared by one of the many commercial suppliers in Paris. ${ }^{28}$ In both cases the starting point is a flat length of textile. Onto this the tailor had to place his pattern while economising as far as possible and having regard for the selvedge (self-edge, a compound noun with ramifications for the 
art of portraiture) and the grain or direction of the pile. So the initial conceptualisation of a man's suit was a series of flat cut out shapes even though the outcome would emerge into recognisable form vertically. ${ }^{29}$ Tailoring is therefore in one sense about putting together a synthetic body; the compound noun 'outfit' suggests this role of uniting two units, one organic and one material. One way of understanding the characteristic ensemble of human subjects and their objects in the work of Degas is to think about them analogously as a series of interlocking shapes, some complementing each other some conflicting. Degas often pieced together pieces of paper for his pastels, the seams remaining visible, and in his re-use of poses, in cutting and tracing his methods were akin to those of tailors.

In his portrait of the cellist Louis-Marie Pilet (1868-69) (pl. 4) Degas worked in oil paint on a piece of woven cloth the texture of which is as important to the artist as it is to the tailor since the weave (or grain), as well as the primer laid on it, determines how pigment will adhere. ${ }^{30}$ Pilet is wedged between a table covered in sheet music, a window that offers no view, a black and white lithograph, a cello and an open cello case. For Alsdorf this last resembles an abstracted pair of bodies. However an open cello case also references a coat undone and awaiting the body it will protect. ${ }^{31}$ Upon this vertically hung canvas are represented a plethora of other materials including not only the subject's clothing but (handpainted?) wall paper, the wood and gut of the cello and the wood of the case as well as the velvet of the tablecloth on which the pages are spread. We observe the cut out effect of all these shapes and the way they are compressed into a rectangle as strictly limited as the margins of a length of cloth. While Pilet looks out of a window our eye is drawn back to the shapes and to the conversation between things that must be erect (like window frames) and those that need to be horizontal (like tablecloths). This is a conversation reminiscent of the calculations of architecture - and of tailoring; in both practices concepts are configured in two dimensions but realised in three.

The French word 'pouce' meaning 'thumb' was the unit of measurement until the metric system was imposed, signalling the intricate connections between embodied presence and notions of scale. ${ }^{32}$ While the tailor who created the 'skin' ${ }^{33}$ for a client must cut out morning coat, trousers and gilet from one piece of cloth, ${ }^{34}$ the artist must fit the figure onto an equally rectangular piece of cloth. Accommodating an entity of human scale to a rectangular surface was common therefore to artists and tailors; so is a focus on line whether in the sense of the overall silhouette (a popular art form in this era) ${ }^{35}$ or in the sense of 'delineating' the relations of the forms to the self-edge (selvedge) of canvas or cloth. Degas, according to contemporaries, perpetually advocated drawing: 'Faites des lignes. Faites 
beaucoup de lignes', he is reported to have said ${ }^{36}$ and, although we tend to notice the paint masses that Degas accumulated on his canvases, these areas are invariably marked out by lines. Walter Sickert, discussing what it is to be an artist, remarked in reference to Degas and Whistler, both of whom he knew, that 'artist is only Greek for "joiner" '. ${ }^{37}$ A tailor also is a 'joiner' working with malleable materials to join different sections of cloth into a whole. Through his mother's family, Degas was connected to cotton manufacturers and A Cotton Office in New Orleans (1873) (pl. 5) which features his brother's portrait not only shows the raw material being handled, and lengths of woven textile on shelves, but also reveals this interest in what it meant to register what was horizontal in relation to what was vertical. ${ }^{38}$ These relationships are profoundly investigated in his work, as for example in Conversation chez la Modiste, in L'Absinthe or in the scenes of laundresses ironing in which cloth is spread on flat surfaces to be pressed in order then to be worn by subjects who are vertical. ${ }^{39}$ Garments are largely worn vertically but the textile from which they are made is pressed in the manufacture and by tailors, launderers and by the pressure of bodies wearing it.

The difference between a fashion plate and a painting by Degas is not the difference between factual information and impression. Both are fictions. It is clothing as worn (both in the sense of body impressing cloth and in the sense of worn as degraded) that interested Degas. In 1876, Louis Edmond Duranty, echoing Charles Baudelaire's 'Painter of Modern Life' (1863), published an oft quoted essay titled 'la Nouvelle Peinture'. ${ }^{40}$ Writing of Degas, though he is not named, Duranty declared it is time to bid farewell to the human body treated like an elegantly shaped vase (perhaps thinking of male figures in fashion plates); what is needed is what distinguishes modern man in his clothes in the milieu of his social habits:

La donnée devient singulièrement aiguë, c'est l'emmanchement d'un flambeau avec le crayon, c'est l'étude des reflets moraux sur les physionomies et sur l'habit, l'observation de l'intimité de l'homme avec son appartement, du trait spécial que lui imprime sa profession, des gestes qu'elle entraîne à faire, des coupes d'aspect sous lesquelles il se développe et s'accentue le mieux. Avc un dos, nous voulons que se révèle un tempérament, un âge, un état sociale; par une paire de mains nous devons exprimer un magistrat ou un commerçant; par un geste, toute une suite de sentiments.' ${ }^{41}$

(The facts become singularly penetrating: this is equipping the pencil with a flaming torch, it's the study of moral reflections on physiognomies and clothing, the observation of man in the privacy of his apartment, of that special trait stamped on him by his 
profession, the gestures it causes him to make, cross section of the aspects of his life that allow him to grow best and cause him to stand out most. With a back, we want a temperament to be revealed, an age, a social state; with a pair of hands, we must express a judge or a merchant; by a gesture, a whole string of feelings).

In Portraits à la Bourse (1878-9) (pl. 6) we notice in these representations of men seen from behind how the vent in a frock coat (pl. 7 a) parts in ways suggestive less of sudden movement than of the repeated actions of the wearer as he routinely sits and moves, bends and turns. These vents were miracles of tailoring ( $7 \mathrm{~b}$ ): the drap is pleated and turned back, the weight of the button (partially obscured), ensures that the tail hangs correctly. Sometimes a pocket was subtly inserted into the coat tail (where it was accessible from the inside edge of the vent) or into a waist seam; in both cases it was completely hidden from view. ${ }^{42}$ Bespoke garments, coats like this interacted with the man who inhabited them and were imprinted by their owner's habitual actions. Degas was sensitive to all the nuances of men's clothing as worn: we apprehend that the hand on the shoulder might next minute move to the pocket whose opening we see ready to receive it. Creases and crumples and the deliberate blurring of boundaries, the overlapping between coats and trousers, the ambiguity about where a trouser leg terminates or an arm enters a sleeve, all are calculated to convey a material world in which people inhabit clothes in environments that play a part in shaping those clothes. The revelation of a temperament in a back is not arrived at accidentally, and then reflected in a painting; it is the consequence of an unwitting contest in which the artist picks up intuitively the construction of the coat and thereby reinforces it. Equally, as I will later show, he may subvert it. By 'construction' I mean precisely something architectonic: coats are built up with layers of padding following the line of the shoulder blades, and multiple sections grafted together. ${ }^{43}$

The process whereby the tailor and the artist reached their conclusions may be understood as homologous. Like painting tailoring involves graduated layering and interleaving. What makes tailoring an intensely haptic process (like sculpture) is that cloth is manipulated, eased and moulded into seams in order to fit tightly at the waist and swell over the buttocks. Interfacing and padding guarantee the shape of a coat, amending where necessary the physique of its wearer; lapels, reveres and fastenings require parts to be folded back upon themselves or superimposed over another section; layers of stiff canvas are concealed within the upper parts of a wool coat. ${ }^{44}$ Pad stitching (pl. $7 \mathrm{c}$ ) picks up no more than a thread and allows the tailor to manipulate where the lapel should lie. The layering that 
goes to make the painted depictions of these men inflects not only the invisible body with its white hard bony frame superimposed by muscle and mobile skin and then by wool, but also the process of making the portrait by stretching canvas on a frame, laying a ground (whether or not that is done by the artist himself) and then applying mobile pigments and registering through calculated movements marks that evince the embodied mobility of the artist at work. Certain parts of the portrait process - like the sketch, the ground and the under-painting if there is any ${ }^{45}$ - often more or less disappear when the picture is complete. Similarly in the completed garment tailor's tacks and interfacing are not shown. Degas was known for his drafting, redrafting, cancelling and tracing ${ }^{46}$ and in many works by Degas and Manet layers are left exposed in a controlled dialogue between revelation and effacement. The hand of the tailor likewise remains implicit in the cutting (now inferred rather than seen) and explicit in the stitching, some of which will remain on the surface like an artist's brushstroke or even his signature, and in the garment's construction that reveals itself as when a coat is turned inside out.

The preoccupations of nineteenth-century writers juxtapose clothed male bodies with skin and fur on the one hand and with the classical nude as seen in sculpture on the other. ${ }^{47}$ For Théophile Gautier the male body had become invisible: clothing 'à l'époque modern, est devenu pour l'homme une sorte de peau don't il ne se sépare sous aucun prétexte et qui lui adhére comme le pélage à l'animal, à ce point que la forme réelle du corps est de nos jours tout à fait tombée en oubli' (clothing in the modern epoch, has become for man a sort of skin from which he does not separate himself under any pretext and which adheres to him like the pelt of an animal, to this point at which the actual form of the body has in our time altogether fallen into oblivion). ${ }^{48}$ While battles were fought in the Salon over the appropriate way to represent the nude female body, it was ironically within tailoring with its newfound penchant for codification that the ideal of the academic male nude was reconciled with the idea of modernity and individuality. 'Who is your tailor?' was, and in some circles still is, an important question. As Gautier put it: 'il faut qu'on sente qu'un homme est bien mis, sans se rappeler plus tard aucun détail de son vêtement. La finesse de drap, la perfection de la coupe, le fini de la façon et surtout le bien-porté de tout cela constituent la distinction.' (One must feel that a man is well composed, without remembering later a single detail of his clothes. The fineness of the wool, the finish of the making, the perfection of cut, and above all the bearing of the whole thing, all that constitutes distinction) ${ }^{49}$

For all their differences therefore, tailoring and portraiture might both be said to be concerned with the uneasy relationship between divergences from the norm and an ideal of 
the body. The belts and corsets worn by Baron Hulot, in La Cousine Bette, to disguise his corpulence were a means to reconcile these differences. ${ }^{50}$ Tailoring strove to keep the ideal alive while producing subjects that epitomised the modern male. Portraits of men in their contemporary padded and reinforced coats thus form a link in a chain that keeps alive the ideal body but within the context of a mechanical and industrial aesthetic, that of visualising, measuring and projecting, that simultaneously threatens to undermine that ideal. However, if tailoring was about correcting anomalies, painters (as Duranty recognised) were fascinated by those very idiosyncrasies that resulted from usage, aspects of wear that were problematic for tailors. One of the major preoccupations of tailoring was with controlling and as far as possible eradicating creases and folds. These were certainly permitted as we can see in plates for manuals like Cours de Coupe de

Tailleur. ${ }^{51}$ But they were premeditated and predictable folds. Trousers were regarded as particularly difficult - indeed 'impossible' - because of the 'varied relation the legs bear to the body in different attitudes and under various circumstances.' Underlying this is the unstated question of which side a gentleman dressed. ${ }^{52}$

When the body is in the trousers it makes room for itself, consequently, if the fork quantity is small, a tightness will be felt, and a number of creases will appear; if not in the front they will do so at the back, and the material which supplies these creases is drawn from the body of the trousers, so that the waist of the trousers is drawn down from the waist of the figure, causing anything but a comfortable fit. ${ }^{53}$

Defects in trousers cause any one or more of a typology of folds: horizontal, perpendicular, diagonal, horseshoe. ${ }^{54}$ The tailor's conceptualisation of the body in these publications is one of the morselised subject: different sections of the body are viewed as discrete and are systematically projected onto two-dimensional surfaces. A tailor's measurements, one might say, are his portrait of his client (and one that was permanent in the sense that, retained by the tailor, it outlived the garment and could be reinvigorated as necessary). But artists not only endorsed the aims of tailoring, they also subverted them. If we look at the trousers worn by Fantin-Latour in his self-portrait (pl. 8) what we see is a tailor's nightmare: a positive cascade of folds and creases of every sort is fixed in perpetuity at the eye level of the viewer. In contrast with the extended blurry outline of the left arm in its sleeve, the artist dwells upon the elaborate creases in his own trousers; where the trouser leg rumples as it falls over his shoe, brush-strokes in varied shades of grey follow the contours of the folds. For all the 
darkness of his clothing, Fantin-Latour employs very little actual black: one typical area is where a streak of raised black impasto indicates the creases where left leg crosses right. The artist's gaze is occluded, his expression uncertain, but his trousers are immensely individual in their materiality.

\section{Painting and Dyeing}

In Fantin-Latour's self-portrait (pl. 8) crumples invite an inspection of pigment patina as equivalence of textile and at the same time represent the movement of that textile. If we want to be reminded of men's fashions, we must turn to James Tissot, but what the portraits of Manet, Degas and Fantin-Latour emphasise is the instability of these subjects their tendency to crumple. ${ }^{55}$ The fashionably dressed male body, for all its apparent authority seemingly reinforced in portraiture and in photography, is subject to remorseless processes of disintegration. Many of the pigments that are used to depict his stylishness derive from various kinds of soot, the smart paletot he wears will fade if exposed extensively to sunlight, its colour may penetrate his veins and affect his metabolism without an interleaved layer of linen akin to the protective priming layer between paint-layer and canvas, the quality of cloth may be an illusion, and his trousers may end up as rags. Moreover the trousers, waistcoat and coat he wears are made up of pieces cut from a length and could be unpicked and returned to that fragmented and seemingly illogical collection of pieces, whose very fractured history is hinted at in so many lines and streaks of paint, as well as in the truncation of legs and feet that occur in many of these portraits, not to mention the ghostly existence of hands and body parts that have never fully materialised. Folds and creases are part of this visible construct in which the breaking up of the idealised impenetrable surface is registered - a shadowy foretaste of what Cubism would teach us.

What, then of the funereal aspect of the urban male to which a wide variety of contemporary texts have attested? In Paris Herself Again (1879) George Augustus Sala, remembering the winter of 1854, describes an incident when one of his 'band of young English and American brothers domiciled in Paris' was invited to a grand ball. As he lacked the 'requisite black pantaloons of fashionable society', a collection was organised and at the Marché du Temple, then a gigantic second-hand clothes market, he purchased 'a pair of the blackest and shiniest trousers ever beheld.' At the ball at the Hôtel de Ville, he partook copiously of the refreshments and when a friend drew his attention to the fact that he had allowed some punch to trickle over the knee of his trousers, he wasted no time in rubbing the 
offending spot. He rubbed and rubbed but the spot did not disappear but grew larger and larger, and became at last a brilliant red. 'In the midst of an ocean of shiny black there was disclosed to his alarmed eyes an island of the pattern and hue of the Royal Stuart tartan. ${ }^{56}$

The hallmark black that was so essential to a man's wardrobe, that 'black-frock coat and tail-coat' that Baudelaire described as the 'uniform of our suffering age', remarking in 1846 'all of us are attending some funeral or other', proves illusory. ${ }^{57}$ The dye used to transform a pair of trousers purchased in the second hand clothing market that was the underbelly of Parisian fashionability turns out to be unstable, no more than a fiction. ${ }^{58}$ And as the former life of the trousers is revealed in a patch of brightly coloured tartan, it is not only the fiction of the garment that is exposed. So too its wearer's social status is exposed as a pretence. What seemed real is false; seepage and instability appear where there should have been certitude and authenticity. In the same year Flaubert wrote: 'Nous sommes tous des farceurs et des charlatans. Pose, pose et blague partout!' (We are all jokers and charlatans. Affectation, affectation and farce everywhere). ${ }^{59}$ His list of those consumer objects that he regards as contributing to the gigantic ugliness that industrialisation has thrust upon Paris include the mackintosh, fake luxury, false pride - and false textiles. ${ }^{60}$

Concern about stability of dyes went hand in hand with anxiety about the durability of textiles, about their appearance, and the implications of both for hygiene. Augustin Canneva, in a passage that brings to mind the matte surfaces of Degas's oils, warned against too much shine on cloth:

Le brilliant, lorsqu'il est factice, c'est a dire obtenu par trop d'apprêt, disparait au décatisage; il est pourtant facile de reconnôitre un drap trop appreté a son reflet blanchâtre et a son poil toujours un peu dur et collé.

On donne ordinairement beaucoup d'apprêt aux draps qui sont hauts de laine, c'est a dire mal tondus, pour voiler en quelque sorte de défaut, mais on peut juger de la hauteur du poil en regardant le pli du milieu, qui ne prend pas d'apprêt. ${ }^{61}$

(Sheen, when it is simulated, that is obtained by too much finishing, disappears in the hot pressing; it is therefore easy to recognise an overfinished cloth by its whitish reflection and by its pile which is always a bit hard and sticky.

A great deal of finishing is ordinarily given to textiles which are of fluffy wool, that is to say, badly shorn, to hide this fault to some extent, but one may judge the height of the pile by looking at the centre fold, which is not treated with the finishing.) 
This concern with 'finishing' is in parallel to the importance to artists of the texture and priming (finish) of canvas. Degas often chose to use fine and relatively smooth weaves and also worked extensively on paper that was smooth. ${ }^{62}$ Canneva advised that the permanence of dye can be tested with a drop of hydrochloric acid (acide muratique) and that certain colours (all of them dark or black) are not to be trusted as over time they are subject to fading. It was not only second-hand clothing that might prove unreliable in terms of colour:

Il-y-a des couleurs qui, bien que bon teint, sont moins solides que certaines autres, et qui nuisent même à la durée des draps; tels sont les couleurs noires, marengo-noire, grenat, violette, pomme-de-chêne, etc. ${ }^{63}$

(There are colours that, even if colour fast, are less solid than others, and which over time damage the textiles; such are the black colours, marengo-black [a greyish black], ${ }^{64}$ grenat [dark red], violet, oak apple, etc.)

Clothing and household furnishing that were discoloured signalled poverty or a disconnect with the modern world. In Bleak House (1852-3) Dickens conveyed the senescence of the lawyer and of the Law in his description of the 'rusty' appearance of the black clad ancient Attorney at Law. ${ }^{65}$ In a paper delivered to the Académie des Sciences in 1860 Michel Eugène Chevreul pointed out that the mechanisms that had controlled the quality of dyeing in the time of Colbert no longer pertained: 'l'acheteur d'une étoffe mauvais teint, quelque soit le prix qu'il a payé, n'a pas de recours sur le vendeur comme il en avait autrefois.' (the purchaser of a badly dyed cloth, whatever the price he has paid, has no recourse to the vendor as he previously had. $)^{66}$

The chemical stages gone through to produce a black dye were many. As one classic account of the techniques of dyeing points out black 'includes a prodigious quantity of shades' but many do not take sufficient pains with the process and are satisfied once they have got the cloth to a blue tint to dip it in a decoction of nutgalls and let it boil for two hours. A good black, the author observes, should be 'velvety' and not of a 'reddish cast disagreeable to the eye'. ${ }^{67}$ Thus a black suit started off life as a length of cloth of a completely different colour - generally blue or brown - which went through many vats of dye and fulling processes before reaching a tailor's bench. As Victoria Finlay remarks: 'there are no true black dyes. ... What many people did was dye clothes in several vats - 
blue, red, yellow - until the impression was one of blackness.' ${ }^{68}$ These techniques remained in use even as technology of colouring cloth was fast evolving, and what had been a craft was now an industry. In 1855, the first dye made from tar inaugurated semi-synthetic dyestuffs into a craft that had been confined to natural materials. ${ }^{69}$ By the 1870 s Berlin, Basel, Manchester, Lyon and Mulhouse had huge dyehouses in vast factories employing thousands of workers; gradually aniline dyes were transforming the colours available to the designers of women's dress. ${ }^{70}$ As Esther Leslie points out, dark coal would become the very stuff of organic chemistry, as well as of industry, making beautiful colours from a discarded product of coal, transmuting waste into 'gold'. ${ }^{71}$ But colour fastness remained problematic and remains so to this day as anyone who accidentally puts their black socks in the machine with their whites knows too well. Despite this black remained an essential element in men's clothes, inextricably bound up with class, profession and decorum.

Along with habitation and diet, clothing was understood as one of the means by which the body was regulated in relation to the external world. It was therefore part of nature as well as culture: 'c'est assez dire que le vêtement est dans la nature' (it's enough to say clothing is in nature). Dress should be chosen to 'régulariser le jeu des organs profonds, par le degré de stimulation de la peau, et à lutter par la mobilité des moyens protecteurs avec la mobilité des états thermométrique, hygrométrique, électrique, etc. de l'atmosphère.' (regularise the play of the deep organs, by the degree of stimulation of the skin, and by the mobility of protective means to combat the thermal, hygometric, electric movements etc. of the atmosphere). ${ }^{72}$ Black was recognised for its heat retention and absorption and doctors were rebuked for wearing a colour that could easily absorb 'les emanations odorantes' (smelly emanations) thus threatening their own and their patients' health. ${ }^{73}$ Along with elements in the environment that might penetrate the clothing, there were perceived dangers from soluble dyes that might penetrate the skin and get into the veins as well as the abrasive effect of wool on skin. ${ }^{74} \mathrm{We}$ are reminded again of the importance of the chemise, always so present - even if minimally in terms of paint area - in the portraits I am discussing. The single streak of white pigment transforms not only the darkness of the clothing but indicates a layer of cloth that we do not see - a second skin to the one identified by Baudelaire. ${ }^{75}$ Thus in a portrait by Carolus Duran (pl. 10) white linen shares the same conceptual and material space as the white face while dark clothing merges with dark hair and leeches into the background. Even the suggestions of a certain bagginess in the coats and jackets worn by Degas's sitters invokes the discourses of the hygienists: anything that constricts the body 
should be avoided - tight waistcoats are as bad as corsets - and when buttoned should not exert any pressure in order to avoid the compression of blood vessels and nerves. ${ }^{76}$

By contrast with the extreme unreliability of black dyes, artists' pigments (like the men's fashions represented) were remarkably stable and their origins were natural, like those of dyes. Artists' blacks derived from four sources, all of which were based on carbon: lamp black (noir de bougie) based on soot, ivory black (noire d'ivoire) which was generally not made from ivory but from burned animal bones (and in the past possibly human bones), black from charred peach stones (noir de pêche - a pigment that goes back to the Renaissance), and vine black made from charred vine twigs. ${ }^{77}$ As Anthea Callen has pointed out, Impressionist painters employed 'coloured blacks'; ${ }^{78}$ when mixed, coloured pigments combine subtractively, absorbing light and producing a dominant black effect in a process contiguous with that in dyeing. Although these 'coloured blacks' in Impressionist paintings were produced by mixing a range of colours like red, green and blue, what appeared on the canvas was relatively extremely stable in contrast to the treacherous black of dyed cloth $-\mathrm{a}$ black that might deceive the wearer and viewer. So portraits presented a degree of blackness however brownish or greyish that was dependable to the point of seeming permanent in inverse relationship to the dress worn by those depicted. The hiding power of carbon-based pigments is excellent; transparency is not one of the characteristics of ivory/bone black. ${ }^{79} \mathrm{It}$ is therefore striking to observe how Degas counterintuitively often renders areas of black clothing as semi-transparent in both men's and women's dress. ${ }^{80}$

It would seem that here the interests of artists and of those dyeing cloth and making men's clothes diverged. However, Degas in particular strove to convey these instabilities through his painting technique, and especially through his conclusive 'unfinish', arriving at a magisterial but nonetheless approximate correspondence between the details of dress as worn and as represented. ${ }^{81}$ The creative possibilities of approximate blacks can be seen in Degas's portrait of himself and the artist Evariste de Valernes painted around 1865 (pl. 10). The portrait is generally described as unfinished in the conventional sense, permitting us to observe the artist at work, painting 'alla prima' - that is onto a white primer with no further coat of ground, which was normally reddish brown for landscape and green for figure painting (enabling the artist to work from darks to lights). What is noteworthy, however, is the handling of Degas's companion's black coat. To be sure, we could explain this degree of 'unfinish' by the convention that artists concentrate on heads and hands. But the extent of uncertainty not only over exactly where the contours of this subject's body should be (not to mention his left hand) but also over whether he is wearing a short jacket or a longer frock 
coat, ${ }^{82}$ and whether the coat worn is black, blue, brown or grey - or any other combination of these tints - are not only technical issues but also semantic. In short, the meandering outline of the torso, the ambiguities around what length of coat de Valernes is wearing, and the way the black of the coat seems to discolour the white linen of the collar and seep into the grey of the trousers manifest an approach to portraiture in which the technologies of tailoring and dyeing impinge upon and mobilise ways of representing another human being as a social entity. Degas assigns to painting a series of environmental, reactive and vital attributes; keeping in play the entire range of possibilities of how a garment is constructed, what it is, and what colour it is, he produces an effect as though, in a measured way, the canvas has been in parts saturated with black pigment, making this black and its material history in and of itself a subject to complement the depiction of his friend and his clothes. Reciprocity between textile and colouring substance is the chemical hallmark of dye. Degas subversively extends this relationship to paint. ${ }^{83}$ By so doing he places in doubt the received wisdom concerning the difference between dye and pigment, a difference predicated on permanence.

\section{Painting and Photography}

Black had been the highest fashion colour for the European aristocracy during the fifteenth and sixteenth centuries and into the seventeenth when one contemporary spoke of the hellish customs of an age of materialism expressed in a universal love of black in Dress. ${ }^{84}$ It has been suggested that morality drove the technical development of blacks when the Reformation demanded sombre tones. The pairing of black and white that had been familiar since the development of printing was endorsed by photography. Moreover, as has been widely recognised, at the very moment Impressionism analysed the world in terms of colour and light, photography brought into vision a world seen in black and white. ${ }^{85} \mathrm{~A}$ google search under 'Degas in black and white' gets a large number of hits and many unattributed quotations from the artist himself. Most frequently repeated is the remark he is alleged to have made in 1906: 'If I could live my life again, I should do nothing but black and white'. ${ }^{86}$ Degas's use of monotype for a range of subjects from brothel scenes to landscapes was technically experimental, involving smears, wipes and traces in which it has been argued (as in the 1890 landscape series) the visible world, was supplanted by a visionary world akin to symbolist art. ${ }^{87}$ Equally experimental was his use of photography 
that he took up with great enthusiasm, organising his subjects in a draconian manner and going to great lengths to attain the lighting effects he wanted by distributing oil lamps around interiors in which he posed friends and family. ${ }^{88} \mathrm{He}$ also experimented by manipulating negatives, imposing one view on top of another thereby insisting on a double reading and reversing dark and light, positive and negative. Degas also had himself photographed professionally on many occasions and at least on one occasion copied a photograph in order to paint a portrait. In 1860 Disderi had taken a carte de visite photograph of the Prince and Princess Metternich. Degas's portrait (ca. 1865) reproduces the photograph of Pauline de Metternich in isolation; the Prince is, in Scharf's words suppressed. ${ }^{89}$ Degas then proceeds to work over the image in ways that transform it: a patterned wallpaper is introduced that invades the sitter's body, her face is smeared so it is out of focus, and the pink paint used to depict her blouse seeps onto the buttons. Degas kept this work and it was in his studio at the time of his death. In this painting, photography as an art that replicates the world is harnessed only to be subverted: the issue of focus so central to early photography (and which Julia Margaret Cameron also chose to eschew) is replayed in paint as a question of (un)finish.

In the final section of this essay, I shall consider Degas as a photographer and as a photographed subject not in order to establish an innovative turn in the artist's old age, to reiterate the importance of Degas's predilection for posing photographic subjects for his art in other media, or to convey the importance of the lens view for his perspectives. ${ }^{90}$ The idea of the 'snapshot' image with which Degas has been associated is not part of my argument. ${ }^{91}$ Rather, I am concerned with the long exposures required of sitters as a way to endorse and further question the technologies of painting, tailoring and dyeing: my interest is in the way the accidental and unwanted characteristics of cloth explored in painting penetrate photography, revitalising the material. On one occasion Degas instructed his friend Halévy to arrange his photographic subjects in order to reveal Uncle Jules's 'famous legs' that the artist always 'mentioned ecstatically'. Those legs were clad in trousers and thanks to both the lighting and Uncle Jules's awkward grip on his ankle (as instructed by Degas) they remain one of the clearest and most vivid components in what is a blurred and surreal interior in which identical protagonists reappear turned to ninety degrees. ${ }^{92}$ These blurrings and superimpositions, as well as the patchwork of framed pictures on the wall behind, are entirely consonant with the way in which in the portrait paintings discussed earlier the cutout and focused elements of dress are deliberately rendered ambiguous by overlappings and seepages. The now popular carte-de-visite offered a vision of certitude (guaranteeing the 
presence of a visitor just as their signature on a document would have done). Degas, however, seized upon photography as a medium in which to continue experiments in paint that explored the semantic relationships between object and medium. ${ }^{93}$

There are many other ways in which Degas's late experiments with photography serve to highlight some of his earlier preoccupations in painting. The effects of chiaroscuro and lamps producing a raking light, emphasising a trouser-clad knee, are already found in the illuminated veined hand of Morbilli (pl.3). ${ }^{94}$ Generally seen as Fashion's handmaiden ${ }^{95}$ photography in this period could also show what fashion strove to eliminate - or to ignore. The long exposures required for early portrait sittings, and the requirement of bright light revealed aspects of the subject/object that would not normally be noticed. Lines of corsetry, structural seams, the propensity of cloth to crumple might become visible, as with an aerial photograph that reveals to archaeologists the contours of buildings long vanished. Nadar's photographs show ill-fitting sleeves, the elbow rubbed threadbare, a waistcoat straining against the belly beneath it. ${ }^{96}$ Degas was a fashionable dresser and, as we have seen, understood clothes and how they were made; his many drapery studies evince his intense interest in how cloth behaved. In one photograph he is shown standing next to a table on which his top hat is laid, the creases in his trousers echoing the turned wood legs of the table; in another he rests his bottom on the table and we see as well the many folds of his coat that he has pulled to the side. These photographs manifest as full an array of varying folds as any tailor could have adumbrated..$^{97}$

The 'defect' of the fold that Degas engineered around Uncle Jules's knee was a part of what had become, in early portrait photographs, a kind of visual poetry melding the body and dress of a man for perpetuity. The folds and creases are as individual as the lines on a subject's face. It is Walter Benjamin who eloquently dilates on this in his 'Little History of Photography' (1931). ${ }^{98}$ Benjamin discusses the compelling character of photographs made with long exposures that result in the absence of contemporary relevance - the 'synthetic character of the expression was dictated by the length of time the subject had to remain still'. ${ }^{99}$ The subject grows into the picture, as it were. I take this to mean that the ensuing photograph has more in common with the painted portraits I have been discussing than with a snapshot. 'Everything about these early pictures', states Benjamin, 'was built to last'. 'The very creases in people's clothes have an air of permanence'. Illustrating the point by reference to a photograph of Friedrich Wilhelm Joseph Schelling (1775-1854) (pl. 11), Benjamin appeals to the reader: 'Just consider Schelling's coat. It will surely pass into immortality along with him: the shape it has borrowed from its wearer is not unworthy of the 
creases in his face. ${ }^{100}$ Leaving aside considerations of 'artistic perfection' or 'taste', Benjamin associates these early photographs with an aspiring bourgeoisie, but in order to make this claim he draws attention not to faces or poses or studio paraphernalia but to 'an aura that had seeped into the very folds of the man's coat or floppy cravat. ${ }^{101}$ In Esther Leslie's words: 'sitting in his home and sunk into his creased clothes, [Schelling] exuded duration and familiarity. Each crease in his garments recorded his longevity at the same time as it recorded the photograph's long duration of exposure'. ${ }^{102}$ The question of class is not one that is germane to my argument; rather, what I want to notice is the reification of clothing's behaviour and how that fixes the sitter into a kind of permanence. The same is true of a photograph that Degas took of himself (or had someone take, though he surely arranged the sitting) (pl. 12) in which his head, seen in profile, is flattened almost to a classical relief (emblematic of western culture's longue durée) but the folds of his smock are recorded in extraordinary and palpable detail, as are the two garments (coat? dressing gown?) that hang immediately behind him. The vertical folds of these garments, awaiting the body that will animate, possess the gravity a Parthenon metope. It is as though Degas, in advanced age, is conveying not only the time of exposure and his time of life, but the afterlife of clothing that will, like the photograph, endure after his decease as an autograph memento mori.

In these photographs by, and of, Degas the tenuous insistence of fashion and the illusory arts of the tailor are fully assimilated; the indexical characteristics of cloth as garment with all its associations of adaptation, re-circulation, and degradation testifying to particular acts of wearing by unique individuals, are given permanence. Degas's portraits, his photographs, and the photographs in which Degas is the subject, however different in appearance, share the effect of dismantling Baudelaire's black livery of the undertaker's mute and reassembling it as an image in which the accidental and unwanted aspects of the technologies of tailoring and dyeing, are made to endure through the technologies of painting and photography. 
I would like to thank the editors of Art History for their encouragement. For patiently responding to my questions, and in some cases generously reading drafts, I thank Patrizia di Bello, Edwina Ehrman, Allison Goudie, Kathrin Hoffmann Curtius, Timothy Long, Victoria Mitchell, Aileen Ribeiro, Anna Robins, Clare Rose, Ashok Roy, Aris Sarafianos, Lindsay Smith and Richard Thomson. A special thank you to Anthea Callen for her generous and inestimable advice. First thoughts about Degas were aired at the Colloquium on Portraiture and Materiality at the Clark Art Instutute, 2013. I am also grateful to staff and students at the University of York and the organisers of the 2015 Humboldt University conference 'Signs and Symbols: Dress at the Intersection between Image and Realia' where early versions of this paper were presented. All translations are the author's unless otherwise credited, and any lacunae are my own.

1217.8 x 143.5 cm, London: National Gallery. Louis de Schwiter (1805-1889). Although a close friend of Delacroix, there is no evidence that Degas had a relationship with Schwiter. According to an unpublished note in Degas's hand, the portrait was bought at the sale of Schwiter's collection by a dealer who sold it to Degas in June 1895 in exchange for three pastels, Jean Sutherland Boggs in Boggs, et al eds., Degas, New York, Ottawa, 1988, Part IV, 1890-1912, 393. On the portrait chez Degas see Ann Dumas ed., The Private Collection of Edgar Degas, New York, 1997, I, 15, 36.

2 Bridget Alsdorf, Fellow Men; Fantin Latour and the Problem of the group in NineteenthCentury French Painting, Princeton and Oxford, 2013, ch. 1.

3 I have adopted this formulation from Caroline van Eck, Miguel John Versluys and Pieter ter Keurs, 'The biography of cultures: style, objects and agency. Proposal for an interdisciplinary approach', Cahiers de l'École du Louvre, 7, October 2015, 5. I am grateful to Pieter ter Keurs for alerting me to this.

4 John Harvey, The Story of Black, London, 2013, 7. 
5 See in particular John Harvey, Michel Pastoureau and Esther Leslie (as cited subsequently).

6 Barbara Vinken, trans. Mark Hewson, Fashion Zeitgeist: Trends and Cycles in the Fashion System, Oxford, 2005, 5. See also John Harvey, Men in Black, London, 1995, especially 220.

7 Harvey, Men in Black, 35-6.

8 Honoré de Balzac, 'Traité de la vie élégante', La Mode (October 1830), quoted Ulrich, Lehmann, Tigersprung: Fashion in Modernity, Cambridge, MA, 2000, 25.

9 Augustin Canneva, Livre du Tailleur: Guide Complet .... suivi de l'Hygiène du Tailleur par M. Monneret, D.M., Professeur d'Hygiene, Paris, 1838, 33.

10 Michel Lévy, Traité d'Hygiène Publique et Privé, Paris, 1844, 326.

${ }^{11}$ Philippe Thiébaut, 'An Ideal of Urban Virility', in Gloria Groom, ed., Impressionism, Fashion, and Modernity, New Haven and London, 2013, 138.

12 Walter Benjamin, The Arcades Project, trans. Howard Eiland and Kevin McLaughlin, Cambridge, MA and London, 1999, 67, section B Fashion, quoting Friedrich Theodor Vischer.

13 I do not suggest that this approach is exclusively appropriate to clothing and painting, merely that on account of analogous practices and overlapping techniques they are particularly susceptible to this analytic experiment.

14 See for example Farid Chenoune, A History of Men's Fashion, trans. Deke Dusinberre, Paris, 1993, 66.

15 Pamela Golbin, 'L'homme en noir, l'apparat sans parure' in L'Homme Paré, Paris, 2005, 28.

16 Manuel Charpy, 'The Scope and Structure of the Nineteenth-century Second-hand Trade in the Parisian Clothes Market', in Laurence Fontaine ed., Alternative Exchanges: Secondhand Circulations from the Sixteenth Century to the Present, New York and Oxford 2008, 139-141.

17 Thiébaut, 'An Ideal of Virile Urbanity', 137.

18 H. Despaigne, La Code de la Mode, Paris, 1866, 30, 31 quoted in Chenoune, 70.

19 See Charpy, 'The Scope and Structure', 132. Dictionnaire Universel Théorique et Pratique du Commerce et de la Navigation, Paris,1861 under 'vêtements confectionnés' reported a huge commerce in second hand clothing at the Temple, especially citing military uniforms. 
${ }^{20}$ Kevin L. Seligman, Cutting for All: The Sartorial Arts, Related Crafts, and the Commercial Paper Pattern, Carbondale and Edwardsville, 1996, 27.

21 Seligman, p. 7. Norah Waugh, The Cut of Men's Clothes 1600-1900, London, 1964. In 1863, Heinrich Friedrich Wampen published in London the second edition of his influential Mathematical Instruction in Constructing Models for Drafting the Human Figure. Charles Compaing and Louis Devere published their three-volume The Complete Manual of Cutting, London, 1875-6 including their proportionate pattern measurement system with nine principal conformations.

22 Gustave Flaubert to Louise Colet 29 janvier 1854, Flaubert Corréspondence, 4 eme série, 1854-61, Paris, 1902, 20. For a discussion of the paletot see Chenoune, 65-66.

23 Flaubert, 21.

24 Eugène Chapus in Manuel de l'Homme, 111-112, quoted in Philippe Perrot, Fashioning the Bourgeoisie, trans. Richard Bienvenu (1981), Princeton, 1994, 116.

25 Le Rencontre of 1854 (Musée Fabre, Montpellier) showing the patron deferentially awaiting the artist's arrival.

${ }^{26}$ See for example the Texts and Textiles conference in Cambridge 2012 http://www.english.cam.ac.uk/cmt/?page_id=2630.

27 Canneva, 34-5.

28 Anthea Callen, The Art of Impressionism: Painting Technique and the Making of Modernity, New Haven and London, 2000, 15-125, 30-47.

29 Diderot's Encyclopédie (1765) gives: 'In order to cut a suit, the worker spreads out on his table or workbench the fabric to be made up as well as all the pieces or parts of a suit and the lining, if the pieces need to be lined, in the order they are to be used, one for the right side and the other for the left side. He ordinarily lays the fabric [out] doubled in order to cut the two pieces at the same time. Then he puts on this fabric a pattern or model of the piece he wants to cut; and with the large shears made expressly for the men of this profession, he cuts the fabric all around the pattern, observing while doing so to give the pieces that he is cutting in order to form out of all the pieces [when] stitched and joined together, all the lengths and widths that one has prescribed for them.' http://quod.lib.umich.edu/cgi/t/text/textidx?c=did;cc=did;rgn=main; $v i e w=t e x t ; i d n o=d i d 2222.0000 .124$

30 For a magisterial account of the canvases used by Impressionist artists and their associates, see Callen, The Art of Impressionism, ch. 2, 3, and 4.

31 Alsdorf, 65. The print first identified by Theodore Reff as a reunion in Chopin's studio is discussed by Alsdorf, 62-4. 
32 First introduced in France in 1799 but abandoned due to unpopularity it was re-adopted in 1837.

33 This is the word used by Théophile Gautier, De La Mode, Paris, 1858, 6.

34 Lehmann, 25.

35 Georges Vigarello, La Silhouette du XVII e siècle à nos jours: Naissance d'un Défi, Paris, 2012.

36 'Make lines. Make lots of lines', Walter Sickert, 'The Study of Drawing', The New Age, 16 June 1910, in Anna Robins, Walter Sickert - the Complete Writings on Art, Oxford, 2000, 247.

37 Walter Sickert, 'Daumier's Pictures', Daily Telegraph, 4 February 1925, Robins, 506.

38 On this painting see Marilyn R. Brown, Degas and the Business of Art. A Cotton Office in New Orleans, University Park Pennsylvania, 1994.

39 Conversation chez la Modiste, ca. 1884, Staatliche Museen zu Berlin; L'Absinthe 1875-6, Musée d'Orsay; Repasseuses 1884-6, Musée d'Orsay.

40 The full title is La Nouvelle Peinture: a propos du groupe d'artistes qui exposent dans les Galeries Durand-Ruel, Paris, 1876 (gallica.bnf.fr)

41 La Nouvelle Peinture, 24.

42 This is the case in a frock coat, Museum of London, 39.82.

43 Most scholars have focused on the period post 1900 in the social history of men's tailoring but for some background see David Kuchta, The Three Piece Suit and Modern Masculinity: England 1550-1850, Berkeley, 2002 and Christopher Breward, The Suit: Form, Function and Style, London, 2016, Introduction 'The tailor's art'.

44 I am much indebted to Timothy Long of the Museum of London for making time to talk to me about nineteenth-century tailoring.

45 Degas and Manet often ignored the established convention in this respect and worked without an underpainting.

46 This was observed by Paul Valéry, quoted by Anka Muhlstein, 'Degas invents a new world', New York Review of Books 12 May 2016, 16.

47 This is not only seen in Baudelaire and Gautier but later in Oscar Wilde who stated in 1882: 'at present we have lost all nobility of dress and, in doing so, have almost annihilated the modern sculptor. And, in looking around at the figures which adorn our parks, one could almost wish that we had completely killed the whole art. To see the frockcoat of the drawing room done in bronze, or the double waistcoat perpetuated in marble, adds a new horror to death.' quoted Waugh,156. 
48 Gautier, 6.

49 Gautier, 14-15.

50 Honoré de Balzac, La Cousine Bette (1846), La Comédie Humaine, ed. Marcel Bouteron, Paris, 1950, 158.

51 Cours de Coupe du Tailleur de Paris ou Art d'Apprendre à Couper et Confectionner les Habits d'après le système actuel de mesurage par F. Ladevèze, Paris fourth edn. 1874.

52 Tailor and Cutting Academy 1892 (the author calls himself Oxonian), 6.

53 'Oxonian', in Tailor and Cutting Academy, 11, quoting 'Mr. Williamson'.

54 'Oxonian', 34.

55 James Tissot's The Circle of the Rue Royale (1868), Paris: Musée d'Orsay illustrates as Thiébaut remarks, 139, the entire range of male attire at the end of the Second Empire.

56 George Augustus Sala, Paris Herself Again in 1878-9, London, 1879, II, 216-7.

57 'N'est-il pas l'habit nécessaire de notre époque, souffrante et pourtant jusque sur ses épaules noires et maigres le symbole d'un deuil perpétuel.' Charles Baudelaire, 'De l'Héroïsm de la Vie Moderne', Salon de 1846, in Charles Baudelaire, Critique d'Art, Paris, 1965,174 .

58 Charpy, 'The Scope and Structure', calculates that the Temple had 400-500 shops and thousands of stalls all devoted to second hand clothing.

59 Flaubert to Louise Colet 29 janvier 1854, Flaubert Corréspondence, 20.

60 On rubber clothing, see Manuel Charpy, 'Craze and Shame: Rubber Clothing during the Nineteenth Century in Paris, London, and New York City', Fashion Theory, 16: 2012, 433 460. Translation Chenoune, 70 who, however he uses word 'bunkum' instead of 'farce'. 61 Canneva, 34.

62 Anthea Callen, personal communication June 2016.

63 Canneva, 36.

64 Defined as 'drap à fond noir parsemé de petits effets blancs peu apparents' on the 'Les Nom des Tissus' forum, and as a colour made from grey mixed with brown, named Marengo after the Battle of Marengo, perhaps also the kind of dark grey favoured by Napoleon for his overcoat: http://projetbabel.org/forum/viewtopic.php?p=182746.

65 Charles Dickens, Bleak House, chapter II 'In Fashion', http://www.gutenberg.org/files/1023/1023-h/1023-h.htm

66 Michel Eugène Chevreul, presentation 16 July 1860, printed in Le Génie Industriel:

Revue des Inventions Françaises et Etrangères, vol. 21, 1861, 98. 
${ }^{67}$ Jean Hellot, The Art of Dying Wool, Silk, and Cotton, trans from French (first edn.1750), London, 1789, 181-2, 183-4, 185.

68 Victoria Finlay, Colour: A Natural History of the Palette, New York, 97.

69 Franco Brunello, The Art of Dyeing in the History of Mankind, Vicenza (1968), 1973, 276-8.

70 Anthony S. Travis, The Rainbow Makers: the Origins of the Synthetic Dyestuffs Industry in Western Europe, London and Toronto, 1993, 24-5, p. 50.

71 Esther Leslie, Synthetic Worlds: Nature, Art and the Chemical Industry, London, 2005, $47,76,9$.

72 Lévy, 307.

73 Lévy, 320.

74 Lévy, 316-7.

75 Baudelaire described the frock coat as the outer skin of the modern hero ('Quant à l'habit, la pelure du héros moderne...'), Baudelaire, Salon de 1846.

76 Lévy, 328.

77 Barbara H. Berrie, ed., Artists' Pigments: A Handbook of Their History and

Characteristics, Washington, London, 2007, IV,12-14; the permanence of black pigments are discussed on 14. I am grateful to Ashok Roy for a very illuminating conversation on black, March 2015. Finlay,102, referencing Simon Schama cites the use of human bodies. 78 Callen, The Art of Impressionism, 149.

79 Berrie, 13.

80 A good example of this is the portrait of Elena Carafa, 1875, London: National Gallery.

81 This paper was written before the opening of the exhibition at the Met Breuer New York Unfinished: Thoughts left visible March 2016 but many works on display there suggested the creative potential of these uncertainties.

82 On the various shapes and lengths of coats see Thiébaut, 138.Degas did not employ assistants.

83 As one 1864 technical manual put it: the difference between dyeing cloth and laying paint on canvas is that in dying the pigment bonds chemically with the textile whereas oil pigment in a painting on canvas does not normally penetrate the surface, MM. Barreswil et Aimé Girard, Dictionnaire de Chimie Industrielle, III, Paris, 1864, 479: La coloration des fibres textiles par certaines matières colorantes déterminées n'es pas toujours le résultat d'une simple superimposition mécanique; dans beaucoup de circonstances, la coloration résulte de l'affinité chimique et réciproque de l'étoffe et de la matière colorante. Cette dernière 
distinction séparare nettement la teinture de la peinture. (The colouration of textile fibres by certain defined colouring substances is not always the result of a simple mechanical superimposition; in many circumstances, colouration results from chemical affinity and reciprocity of the cloth and the colouring substance. This last distinction clearly separates dyeing from painting).

84 Tommaso Campanello, quoted in John Gage, Colour and Culture: Practice and meaning from Antiquity to Abstraction, London, 1993, 155-6. An aristocratic colour in dress, black subsequently spread to the bourgeoisie.

85 Michel Pastoureau and Dominique Simonnet, Le Petit Livre des Couleurs, Paris, 2005, $100,97,101$.

${ }^{86}$ Quoted, without a source, in Douglas Crimp, 'Positive / Negative: A Note on Degas's Photographs', October, 5, Summer 1978, 89-100, 100.

87 Crimp, 93.

88 The classic account of this is given by Degas's friend Halévy in 1895 (Daniel Halévy, Degas parle, Paris, 1995,146 and149-150) and is discussed by Crimp, 89-90.

89 Aaron Scharf, Art and Photography (1968), Harmondsworth, 1974, 188. Scharf suggests Degas was attracted to the photograph on account of the striking physiognomy of the subject.

90 Scharf, 187, 193-5.

91 See for example, Scharf, 209.

92 For Degas's instructions and the description of the legs see Halévy, 149-150. These photographs can be viewed at www.photo.rmn.fr/

93 Statement reported by Sickert, quoted in Crimp, 93 without a source. A similar statement is also reported by Berthe Morisot: 'On Thursday Degas said the study of nature was trivial; painting being an art of convention ... Art is falsehood', Anne Higonnet, Berthe Morisot, New York, 1990, 195. Oscar Wilde agreed, stating that he was fond of Impressionist portraits as 'works of pure fiction', in Oscar Wilde, 'The Critic as Artist,' 1891, in The Poems and Essays of Oscar Wilde, Hamburg, Paris, Bologna, 1935, 339. Anna Robins has pointed out that he may have been referring to Whistler (personal communication March 2016). 94 This is pointed out in Malcolm Daniel, Edgar Degas, Photographer, New York, 1998, 29. Degas's insistence on the knee is evoked by Halévy.

95 See for example, Elizabeth Anne McCauley, 'Photography, Fashion, and the Cult of Appearances' in Groom ed. 207.

96 Gaspard-Félix Tournachon, for examples see Atelier Nadar on gallica.bn.fr/. 
97 These can be viewed on www.photo.rmn.fr/

98 The original German is in Rolf Tiedemann and Hermann Schweppenhaüser eds., Walter Benjamin Gesammelte Schriften, II i, Frankfurt am Main, 1977, 368-385; English translation in Walter Benjamin: Selected Writings, vol. II, 1927-1934, trans. Rodney Livingstone and others, ed. Michael W. Jennings, Howard Eiland, and Gary Smith, Cambridge, MA and London, 1999, 507-530.

99 Benjamin, 'Little History', 514.

100 Benjamin, 'Little History', 514.

101 Benjamin, 'Little History', p. 517.

102 Esther Leslie, Walter Benjamin, London, 121. 